\title{
ANALISIS PENGARUH BELANJA DAERAH (BELANJA LANGSUNG DAN BELANJA TIDAK LANGSUNG) TERHADAP PERTUMBUHAN EKONOMI DI KABUPATEN TANGERANG TAHUN 2008 - 2014.
}

\author{
Oleh : Moch. Chamdani \\ Email :mchamdani@unis.ac.id \\ Dosen Universitas Islam Syekh-Yusuf Tangerang \\ Program Studi Manajemen
}

\begin{abstract}
ABSTRAK
Anggaran Pendapatan Belanja Daerah (APBD) adalah rencana keuangan tahunan pemerintah daerah yang ditetapkan berdasarkan peraturan daerah. Alokasi belanja daerah didasarkan pada kebutuhan daerah melalui prioritas anggaran dan pelayanan publik guna memberikan dampak langsung terhadap pertumbuhan ekonomi. Penelitian ini dilakukan untuk mengetahui hubungan kausal empiris belanja langsung dan belanja tidak langsung terhadap pertumbuhan ekonomi di kabupaten Tangerang Tahun 2008 - 2014. Berdasarkan hasil uji T dan Uji F secara parsial bahwa tidak cukup bukti terdapat pengaruh belanja langsung terhadap pertumbuhan ekonomi di kabupaten Tangerang., Tidak cukup bukti terdapat pengaruh belanja tidak langsung terhadap pertumbuhan ekonomi di kabupaten Tangerang. Kemudian secara bersama-sama terbukti terdapat pengaruh simultan dan siginfikan belanja langsung dan belanja tidak langsung terhadap pertumbuhan ekonomi di kabupaten Tangerang. Pengaruh langsung belanja langsung terhadap belanja tidak langsung sebesar 94,9\%, Pengaruh langsung belanja langsung terhadap pdrb sebesar $0,35 \%$, dan pengaruh langsung belanja tidak langsung terhadap PDRB sebesar 63,5\%, kemudian secara bersama-sama belanja langsung dan belanja tidak langsung memberikan pengaruh simultan dan signifikan terhadap pdrb sebesar 89,9\%, dan sisanya $10,1 \%$ dipengaruhi oleh variable lain. Untuk mencapai nilai pertumbuhan ekonomi sebesar 0 pemerintah Kabupaten Tangerang harus menutup defisit nilai konstan sebesar Rp. 132.771.632.99,-, sehingga nilai konstan menjadi positif. Kemudian untuk meningkatkann nilai pertumbuhan ekonomi sebesar 1 digit dibutuhkan alokasi belanja daerah senilai Rp. $6.107 .495,12,-$.
\end{abstract}

Kata kunci : Belanja Langsung, Belanja Tidak langsung, Pertumbuhan Ekonomi.

\begin{abstract}
Local Budget (APBD) the annual financial plan of local government established by local regulations. The allocation of regional spending based on local needs through budget priorities and public services in order to provide an immediate impact on economic growth. This study was conducted to determine the causal relationship empirically direct expenditure and indirect expenditure to economic growth in the district of Tangerang 2008 - 2014. Based on the results partial of $T$ test and $F$ test was not enough evidence that there are significant direct expenditure to economic growth in the district of Tangerang. Not enough evidence there are significant indirect spending to economic growth in the district of Tangerang, and Then together proved no influence siginfikan simultaneous and direct expenditure and indirect expenditure to economic growth in the district of Tangerang. The direct effect of direct expenditure for indirect expenditures amounted to 94.9\%, direct influence of direct expenditure to GDP of $0.35 \%$, and the direct effect of indirect expenditure to GDP amounted to 63.5\%, then jointly direct spending and not spending simultaneous direct and significant impact to the GDP amounted to $89.9 \%$, and the remaining $10.1 \%$ is influenced by other variables. To achieve economic growth at 0 value Tangerang regency government should close the deficit constant value of Rp. 132.771.632.99,-, so that a constant value becomes positive. Then to meningkatkann value by 1 digit economic growth needed regional expenditure allocation of Rp. 6,107,495.12, -.
\end{abstract}

Keywords: Shopping Direct, Indirect Spending, Economic Growth. 


\section{A. PENDAHULUAN}

Pembangunan dipandang sebagai suatu proses multidimensional yang mencakup berbagai perubahan mendasar atas struktur sosial, sikap masyarakat, dan institusi nasional disamping tetap mengejar akselerasi pertumbuhan ekonomi, penanganan pengangguran, serta pengentasan kemiskinan. Pada hakekatnya pembangunan harus mencerminkan perubahan total suatu masyarakat atau penyesuaian sistem sosial secara keseluruhan tanpa mengabaikan keragaman kebutuhan dasar dan keinginan individual maupun kelompok-kelompok sosial yang ada di dalamnya, untuk bergerak maju menuju suatu kondisi kehidupan yang serba "lebih baik", secara material maupun spiritual. Tolok ukur keberhasilan pembangunan dapat dilihat dari pertumbuhan ekonomi, struktur ekonomi, dan semakin kecilnya ketimpangan pendapatan antar penduduk, antar daerah dan antar sektor.

Tujuan utama pembangunan suatu negara adalah untuk meningkatkan kesejahteraan dan kemakmuran rakyat. Menurut Todaro, (2004) "Tujuan utama dari usaha-usaha pembangunan ekonomi selain menciptakan setinggi-tingginya pertumbuhan ekonomi, harus pula menghapus atau mengurangi tingkat kemiskinan, ketimpangan pendapatan, dan tingkat pengangguran. Kesempatan kerja bagi penduduk atau masyarakat akan memberikan pendapatan untuk memenuhi kebutuhan hidupnya".

Dimensi tujuan pembangunan menurut Mudrajat Kuncoro, (2010:5) "Dimensi tujuan pembangunan menjelaskan urutan tahapan evolusi pengukuran ekonomi pembangunan, dari awal kemunculan teori ekonomi pembangunan yang mengukur terjadinya pembangunan dilihat dari tingkat output melalui Produk Domestik Bruto (PDB) berkembang menggunakan Indeks Pembangunan Manusia (IPM) mengatasi kemiskinan dengan paradigma entitlement dan kapabilitas, kebebasan hingga pembengunan berkelanjutan".

Anggaran merupakan alat akuntabilitas, manajemen, dan kebijakan ekonomi yang berfungsi untuk mewujudkan pertumbuhan ekonomi dan stabilitas perekonomian daerah serta pemerataan pendapatan dalam rangka mencapai tujuan pembangunan. Anggaran Pendapatan dan Belanja Daerah (APBD) merupakan instrumen kebijakan fiskal yang merujuk pada kebijakan ekonomi yang dibuat untuk mengarahkan ekonomi suatu daerah melalui pendapatan dan pengeluaran pemerintah daerah. Kebijakan fiskal pada umumnya bertujuan untuk mencapai kestabilan dalam perekonomian daerah dengan meningkatkan secara terus-menerus pendapatan riil suatu daerah pada laju pertumbuhan, faktor-faktor produksi, dengan tetap mempertahankan kestabilan hargaharga umum.

Menurut Undang-Undang No.17 Tahun 2003 Tentang Keuangan Negara Pasal 16, Anggaran Pendapatan Belanja Daerah (APBD) merupakan wujud pengelolaan keuangan daerah yang ditetapkan setiap tahun dengan peraturan daerah (Perda). Struktur Anggaran Pendapatan dan Belanja Daerah terdiri atas anggaran pendapatan, anggaran belanja, dan pembiayaan. Pendapatan daerah berasal dari pendapatan asli daerah, dana perimbangan, dan lain-lain pendapatan yang sah. Belanja daerah dirinci menurut organisasi, fungsi, dan jenis belanja. Pembiayaan daerah meliputi semua penerimaan yang perlu dibayar kembali dan/atau pengeluaran yang akan diterima kembali. 
Belanja daerah berdasarkan Permendagri 13 tahun 2006 terdiri atas: belanja tidak langsung dan belanja langsung. Kelompok belanja tidak langsung merupakan belanja yang dianggarkan tidak terkait secara langsung dengan pelaksanaan program dan kegiatan. Kelompok belanja langsung merupakan belanja yang dianggarkan terkait secara langsung dengan pelaksanaan program dan kegiatan.

Kelompok belanja tidak langsung dibagi menurut jenis belanja yang terdiri dari belanja pegawai, belanja bunga, belanja subsidi, hibah, belanja bantuan sosial, belanja bagi hasil, belanja bantuan keuangan dan belanja tidak terduga. Kelompok belanja langsung dibagi menurut jenis belanja yang terdiri dari belanja pegawai, belanja barang dan jasa, dan belanja modal.

Kebijakan belanja pemerintah diyakini akan mampu mendorong pertumbuhan ekonomi. Didalam teori pertumbuhan endogen, pengeluaran pemerintah memiliki peran dalam pertumbuhan ekonomi dengan asumsi implikasi pengeluaran pemerintah adalah untuk kegiatan produktif misalnya belanja infrastruktur. Belanja yang bersifat produktif dan bersentuhan langsung dengan kepentingan publik akan mendorong meningkatnya perekonomian. Misalnya, pembangunan infrastruktur akan mendorong investasi, dengan adanya investasi ekonomi akan berkembang dan menciptakan lapangan kerja baru sehingga akan menyerap pengangguran dan memperkecil kemiskinan

Pertumbuhan ekonomi diartikan sebagai perkembangan kegiatan dalam perekonomian yang menyebabkan barang dan jasa yang diproduksi dalam masyarakat bertambah dan kemakmuran masyarakat meningkat (Sukirno,2000). Pertumbuhan ekonomi mengukur prestasi dari perkembangan suatu perekonomian dari suatu periode ke periode lainnya yang ditandai oleh peningkatan kemampuan suatu negara untuk menghasilkan barang dan jasa. Kemampuan untuk menghasilkan barang dan jasa akan meningkat bila didukung oleh berkembangnya faktor-faktor produksi baik dalam bentuk kuantitas maupun kualitas. Selain itu, investasi akan meningkatkan jumlah barang modal dan teknologi.

Dalam konteks makro ekonomi, government expenditure (pengeluaran pemerintah) merupakan salah satu variable pembentuk Produk Domestik Bruto (PDB) bersama dengan konsumsi masyarakat, investasi swasta dan net ekspor. Secara teori, kebijakan pengeluaran pemerintah ini merupakan bagian dari kebijakan fiskal yang merupakan salah satu wujud intervensi pemerintah didalam perekonomian untuk mengatasi kegagalan pasar (market failure). "Konsep dasar ekonomi makro indikator yang digunakan dalam mengukur pertumbuhan ekonomi, adalah produk domestik bruto (PDB). Produk Domestik Bruto (PDB) adalah nilai pasar semua barang dan jasa akhir yang diproduksi dalam perekonomian selama kurun waktu tertentu" (Mankiw, 2006: 19).

Hukum Wagner, mengemukakan suatu teori mengenai perkembangan pengeluaran pemerintah yang semakin besar dalam persentase terhadap PDB. Wagner mengemukakan bahwa dalam suatu perekonomian apabila pendapatan perkapita meningkat maka secara relatif pengeluaran pemerintah pun akan meningkat.

Anggaran daerah menduduki posisi sentral dalam upaya pengembangan kapabilitas, efisiensi, dan efektifitas pemerintah daerah dan dipergunakan sebagai alat menentukan besarnya pendapatan, pengeluaran, dan pembiayaan, alat bantu pengambilan keputusan dan perencanaan pembangunan, alat koordinasi bagi semua 
aktivitas di berbagai unit kerja, alat untuk melakukan penilaian secara internal maupun keterkaitan dalam mendorong pertumbuhan ekonomi.

Kabupaten Tangerang merupakan salah satu kabupaten di wilayah pemerintahan Provinsi Banten dengan pusat pemerintahan di Tigaraksa yaitu berada dibagian timur Provinsi Banten dan sebelah barat Kota Tangerang. Kabupaten Tangerang terletak pada posisi yang cukup strategis karena merupakan salah satu kota/kabupaten penyangga Ibukota Pemerintahan Republik Indonesia (DKI Jakarta). Pemerintah daerah Kabupaten Tangerang sesuai dengan kewenangannya setiap tahunnya melaksanakan perencanaan pembangunan daerah yang diwujudkan dalam bentuk Anggaran Pendapatan dan Belanja Daerah. Proporsi anggaran pendapatan dan belanja daerah kabupaten Tangerang Tahun 2008 - 2014 dapat dilihat pada table 1 dan table 2 sebagai berikut:

Tabel. 1.

Proporsi Pendapatan Daerah Kabupaten Tangerang

Tahun 2008 - 2014.

\begin{tabular}{|c|r|c|c|c|c|c|c|c|}
\hline \multirow{2}{*}{ No } & Tahun & Pendapatan & $\begin{array}{c}\text { Pendapatan } \\
\text { Asli Daerah }\end{array}$ & $(\%)$ & $\begin{array}{c}\text { Dana } \\
\text { Perimbangan }\end{array}$ & $(\%)$ & $\begin{array}{c}\text { Lain-lain } \\
\text { Pendptn } \\
\text { Yang Sah }\end{array}$ & $(\%)$ \\
\hline 1 & 2008 & $1,906,738,615$ & $336,934,801$ & 17.67 & $1,255,919,380$ & 65.87 & $313,884,434$ & 16.46 \\
\hline 2 & 2009 & $1,922,811,228$ & $372,841,974$ & 19.39 & $1,376,748,938$ & 71.60 & $173,220,316$ & 9.01 \\
\hline 3 & 2010 & $1,638,706,190$ & $354,765,480$ & 21.65 & $1,021,008,170$ & 62.31 & $262,932,530$ & 16.05 \\
\hline 4 & 2011 & $2,224,307,766$ & $665,231,224$ & 29.91 & $1,288,462,389$ & 57.93 & $270,614,153$ & 12.17 \\
\hline 5 & 2012 & $2,504,685,440$ & $689,427,609$ & 27.53 & $1,542,498,443$ & 61.58 & $272,759,388$ & 10.89 \\
\hline 6 & 2013 & $3,068,018,642$ & $1,033,942,091$ & 33.70 & $1,498,947,578$ & 48.86 & $535,128,974$ & 17.44 \\
\hline 7 & 2014 & $3,725,132,012$ & $1,603,073,638$ & 43.03 & $1,461,378,798$ & 39.23 & $660,679,576$ & 17.74 \\
\hline
\end{tabular}

Sumber: LRA BPKAD Kabupaten Tangerang.

Pada Tabel 1 dapat dilihat bahwa pendapatan daerah terbesar bersumber dari dana perimbangan (transfer) pemerintah pusat, penerimaan dana perimbangan pada tahun 2008 yaitu sebesar 65,87 \%, pendapatan asli daerah sebesar 17,67 \% dan Lain-lain pendapatan yang sah sebesar 16,46\%. Selanjutnya total pendapatan pada tahun 2009 pendapatan asli daerah sebesar 19,39\%, dana perimbangan sebesar 71,60\% dan 9,01\% dari pendapatan lain-lain yang sah. Pada tahun 2010 pendapatan asli daerah sebesar 21 , $65 \%$, dana perimbangan sebesar $62,31 \%$ dan pendapatan lain-lain yang sah sebesar 16,05\%. Selanjutnya pada tahun 2011 pendapatan asli daerah sebesar 29,91\%, dana perimbangan sebesar $57,93 \%$ dan pendapatan lain-lain yang sah sebesar $12,17 \%$. Kemudian tahun 2012 pendapatan asli daerah sebesar 27,53\%, dana perimbangan sebesar $61,58 \%$ dan pendapatan lain-lain yang sah sebesar 10,89\%. Sedang pada tahun 2013 pendapatan asli daerah sebesar $33,70 \%$, dana perimbangan sebesar $48,86 \%$ dan pendapatan lain-lain yang sah sebesar $17,44 \%$. 
Pendapatan daerah terbesar bersumber dari dana perimbangan pemerintah pusat dengan rata-rata perolehan setiap tahunnya sebesar 58,20 \%. Sedangkan rata-rata pendapatan asli daerah setiap tahunnya mencapai $27,55 \%$. Dan pendapatan dari lainlain pendapatan yang sah rata-rata setiap tahun sebesar $14,25 \%$. Bila tinjau dari pendapatan daerah yang berasal dari dana perimbangan (transfer) yang mengalami penurunan setiap tahunnya dan pendapatan asli daerah yang mengalami kenaikan setiap tahunnya dari tahun 2008- 2014 maka dapat dikatakan bahwa Kabupaten Tangerang memiliki peningkatan kemandirian fiskal yang lebih baik.

Selain menetapkan pendapatan daerah pemerintah Kabupaten Tangerang juga menetapkan belanja daerah, proporsi belanja daerah Kabupaten Tangerang pada tahun 2008 - 2004 dapat dilihat pada tabel berikut ini:

Tabel. 2.

\section{Proporsi Belanja Daerah Kabupaten Tangerang}

Tahun 2008 - 2014

\begin{tabular}{|c|c|r|r|r|r|r|c|}
\hline \multirow{2}{*}{ No } & \multirow{2}{*}{ Tahun } & \multicolumn{6}{|c|}{ Belanja Daerah (000.Rp) } \\
\cline { 5 - 9 } & & Total Belanja & $\mathbf{( \% )}$ & $\begin{array}{c}\text { Belanja } \\
\text { Langsung }\end{array}$ & (\%) & $\begin{array}{c}\text { Belanja Tidak } \\
\text { Langsung }\end{array}$ & (\%) \\
\hline 1 & 2008 & $1,690,387,008$ & 100 & $950,172,541$ & 56.21 & $740,214,467$ & 43.79 \\
\hline 2 & 2009 & $2,015,224,698$ & 100 & $1,155,409,218$ & 57.33 & $859,815,480$ & 42.67 \\
\hline 3 & 2010 & $1,783,508,770$ & 100 & $943,139,600$ & 52.88 & $840,369,170$ & 47.12 \\
\hline 4 & 2011 & $2,027,969,594$ & 100 & $1,113,208,712$ & 54.89 & $914,761,028$ & 45.11 \\
\hline 5 & 2012 & $2,556,468,594$ & 100 & $1,427,126,209$ & 55.82 & $1,129,342,384$ & 44.18 \\
\hline 6 & 2013 & $2,871,204,506$ & 100 & $1,696,486,655$ & 59.09 & $1,174,717,851$ & 40.91 \\
\hline 7 & 2014 & $3,512,771,525$ & 100 & $2,245,622,940$ & 63.93 & $1,267,148,584$ & 36.07 \\
\hline
\end{tabular}

Sumber: LRA BPKAD Kabupaten Tangerang.

Pada tabel 2 dapat dilihat total belanja daerah kabupaten Tangerang tahun 2008 s/d 2014 setiap tahunnya mengalami kenaikan sebesar 13.69\%. Proporsi belanja langsung terhadap belanja total tahun 2008 sebesar 56,21\%, tahun 2009 sebesar 57,33, tahun 2010 sebesar 52,88 \%, tahun 2011 sebesar 54,89\%, pada tahun 2012 sebsar $55,82 \%$, proporsi belanja langsung pada tahun 2013 sebesar 59,09 dan belanja langsung tahun 2014 sebesar 63,93\% sedangkan proporsi belanja tidak langsung terhadap total belanja pada tahun 2008 sebesar 43,79\%, tahun $200942,67 \%$, tahun 2010 sebesar 47,12 \%, tahun 2011 sebesar 45,11\%, pada tahun 2012 sebesar 44,18\%, belanja tidak langsung pada tahun 2013 sebesar 40,1\%. dan pada tahun 2014 sebesar $36,07 \%$. Proporsi belanja langsung terendah terjadi pada tahun 2010 dan proporsi belanja tidak langsung terendah terjadi pada tahun 2009 yakni 42,67 \% dari total belanja daerah. Bila kita lihat total belanja daerah setiap tahunnnya mengalami kenaikan kecuali pada tahun 2010 belanja daerah mengalami penurunan sebesar $12 \%$ bila dibandingkan total belanja pada tahun 2009. Sedangkan proporsi belanja langsung dan belanja tidak langsung mengalami penurunan sebesar (-11\%) pada tahun 2010 . 
Tabel 3.

Jumlah Penduduk, PDRB, Inflasi, LPE, IHH, AHH, IPM, Pengangguran dan Kemiskinan Kabupaten Tangerang tahun 2008-2014.

\begin{tabular}{|c|l|r|r|r|r|r|c|c|}
\hline NO & \multicolumn{1}{|c|}{ DESKRIPSI } & \multicolumn{1}{c|}{$\mathbf{2 0 0 8}$} & \multicolumn{1}{c|}{$\mathbf{2 0 0 9}$} & \multicolumn{1}{c|}{$\mathbf{2 0 1 0}$} & \multicolumn{1}{c|}{$\mathbf{2 0 1 1}$} & \multicolumn{1}{c|}{$\mathbf{2 0 1 2}$} & \multicolumn{1}{c|}{$\mathbf{2 0 1 3}$} & $\mathbf{2 0 1 4}$ \\
\hline 1 & Jumlah Penduduk & $3,585,269$ & $2,565,279$ & $2,834,376$ & $2,960,474$ & $3,050,929$ & $3,165,146$ & $3,273,423$ \\
\hline 2 & PDRB harga konstan & $16,647,358$ & $17,382,091$ & $18,549,119$ & $19,736,262$ & $20,865,800$ & $21,923,892$ & $23,159,090$ \\
\hline 3 & Pendapatan Perkapita & 759,970 & 712,222 & 580,248 & 756,271 & 720,038 & N/A & N/A \\
\hline 4 & Upah Minimum Regional (UMR) & 953,850 & $1,044,500$ & $1,117,245$ & $1,243,000$ & $1,723,000$ & N/A & N/A \\
\hline 5 & Inflasi (\%) & 6.25 & 4.02 & 5.59 & 3.6 & 4.3 & 5.88 & 5.69 \\
\hline 6 & Pertumbuhan Ekonomi (LPE) (\%) & 5.33 & 4.41 & 6.71 & 7.35 & 7.45 & N/A & N/A \\
\hline 7 & Percentase Penduduk Miskin & 7,41 & 6,55 & 7,18 & $* 6,42$ & 6,22 & 5,71 & N/A \\
\hline 8 & Indeks harapan Hidup & 67,4 & 67,69 & 67,98 & 68,17 & 68,35 & N/A & N/A \\
\hline 9 & Angka Harapan Hidup & 65,4 & 65,61 & 65,79 & 65,90 & 66,01 & N/A & N/A \\
\hline 10 & Indeks Pembangunan Manusia & 71,14 & 71.45 & 71.76 & $\mathbf{7 2 , 0 5}$ & $\mathbf{7 2 , 3 6}$ & N/A & N/A \\
\hline 11 & Jumlah Pengangguran & 252,574 & 256,372 & 201,956 & $\mathbf{2 0 4 , 3 5 8}$ & $* 197,113$ & N/A & N/A \\
\hline 12 & Jumlah Angkatan Kerja & $1,658,474$ & $1,616,699$ & $1,441,078$ & $1,416,780$ & $1,404,939$ & N/A & N/A \\
\hline
\end{tabular}

Sumber: Bappeda Kabupaten Tangerang di olah

Dornbusch, (2001). menyatakan pengeluaran pemerintah dapat mempengaruhi tingkat output nasional. Pengeluaran pemerintah yang lebih tinggi akan meningkatkan ouput agregat. Sukirno, (2006:168), berpendapat bahwa "Berdasarkan teori pengeluaran pemerintah yang menjelaskan pembelanjaan penerintahan daerah terhadap berbagai pembangunan akan meningkatkan pengeluaran agregat dan mempertinggi kegiatan ekonomi Negara".

Menurut pendapat Darise, (2006:142\&145), “jika dikaitkan dengan pembelanjaan pemerintah daerah yang tercermin dalam realisasi belanja APBD, semakin besar belanja daerah maka semakin besar juga dampaknya terhadap pertumbuhan perekonomian daerah". Kemudian menurut Lincolin Arsyad, (2005:7), "Pertumbuhan ekonomi adalah sebagai kenaikan Produk Domestik Bruto / Produk Nasional Bruto tanpa memandang apakah kenaikan itu lebih besar atau lebih kecil dari tingkat pertumbuhan penduduk atau apakah perubahan struktur ekonomi terjadi atau tidak".

Selanjutnya menurut Hermanto Siregar dan Dwi Wahyuniarti, (2007), "Pertumbuhan ekonomi merupakan indikator untuk melihat keberhasilan pembangunan dan merupakan syarat bagi pengurangan tingkat kemiskinan. Syaratnya adalah hasil dari pertumbuhan ekonomi tersebut menyebar disetiap golongan masyarakat, termasuk di golongan penduduk miskin".

Menurut teori pengeluaran pemerintah yang menjelaskan bahwa pembelanjaan pemerintahan daerah terhadap berbagai pembangunan akan meningkatkan pengeluaran agregat dan mempertinggi pertumbuhan ekonomi daerah. Teori tersebut dapat diartikan bahwa belanja daerah (belanja langsung dan belanja tidak langsung) yang tercermin dalam Anggaran Pendapatan Belanja Daerah (APBD) memiliki hubungan dan pengaruh terhadap pertumbuhan ekonomi. Mengacu pada teori tersebut maka dapat dibangun model teoritik pada gambar 1 sebagai berikut: 
Gambar 1.

Model Teoritik

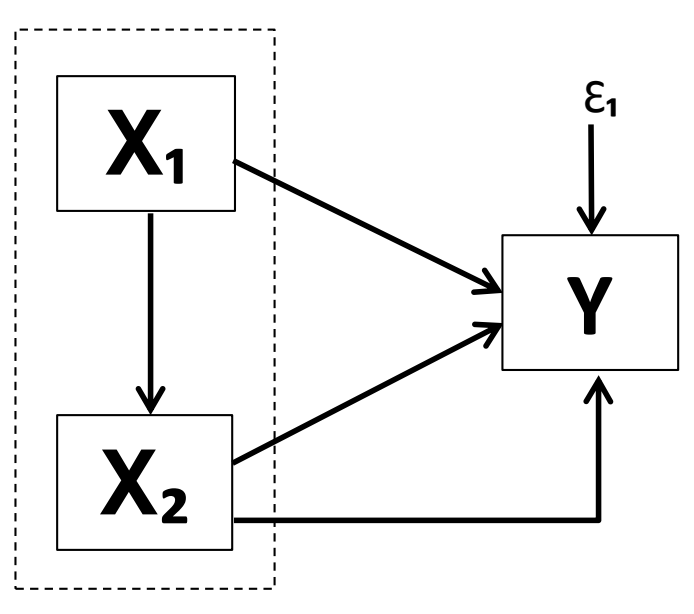

Dari model teoritik tersebut dapat dijelaskan bahwa variable yang akan diteliti adalah Variable Belanja Langsung $\left(\mathrm{X}_{\mathbf{1}}\right)$ dan Variable Belanja Tidak Langsung $\left(\mathrm{X}_{\mathbf{2}}\right)$ sebagai variable bebas (independent) dan Variabel Pertumbuhan Ekonomi atau PDRB (Y) sebagai variable terikat.

Model teoritik ini dimaksudkan untuk mengetahui hubungan kausal empiris antara Variable Belanja Langsung $\left(\mathrm{X}_{\mathbf{1}}\right)$ dan Variable Belanja Tidak Langsung $\left(\mathrm{X}_{\mathbf{2}}\right)$ sebagai variable bebas (independent) terhadap Variabel Pertumbuhan Ekonomi atau PDRB (Y) sebagai variable terikat (dependent).

\section{B. METODOLOGI PENELITIAN.}

Penelitian ini dilaksanakan dengan metode kuantitatif yaitu penelitian dilakukan terhadap data dalam bentuk angka dengan maksud untuk menggambarkan hubungan dan menguji hipotesis yang bersifat hubungan antara variabel mandiri (independen) sebagai variabel yang mempengaruhi dan variabel terikat (dependen) sebagai variabel yang dipengaruhi.

Metode penelitian kuantitatif ini menggunakan metode survey kausal, dimana variable exogenous (bebas) adalah belanja daerah (belanja langsung dan belanja tidak langsung) dan variable endogenous (terikat) yaitu pertumbuhan ekonomi. Model analisis yang digunakan adalah analisis jalur (part analisys) dengan menggunakan program komputer SPSS versi 17.0.

Variabel exogenous dalam suatu model jalur ialah semua variabel yang tidak ada penyebab-penyebab eskplisitnya atau dalam diagram tidak ada anak-anak panah yang menuju kearahnya, selain pada bagian kesalahan pengukuran. Jika antara variabel exogenous dikorelasikan maka korelasi tersebut ditunjukkan dengan anak panah dengan kepala dua yang menghubungkan variabel-variabel tersebut. Dalam istilah lain, dapat disebut pula sebagai independen variabel.

Variabel endogenous ialah variabel yang mempunyai anak-anak panah menuju kearah variabel tersebut. Variabel yang termasuk didalamnya ialah mencakup semua 
variabel perantara dan tergantung. Variabel perantara endogenous mempunyai anak panah yang menuju kearahnya dan dari arah variabel tersebut dalam sutau model diagram jalur. Sedang variabel tergantung hanya mempunyai anak panah yang menuju kearahnya. Atau dapat disebut juga sebagai variabel dependen.

Uji Asumsi Klasik dalam penelitian ini diawali dengan Uji normalitas data yang bertujuan untuk menguji, apakah dalam model regresi variabel independen dan dependen, keduanya mempunyai distribusi normal atau tidak, dengan melihat grafik normal P-P Of Regression Standard-ized residual menggambarkan penyebaran data disekitar garis diagonal yang penyebaranya mengikuti arah garis diagonal grafik. Heteroskedastisitas adalah keadaan dimana terjadinya ketidaksamaan varian dari residual pada model regresi. Multikolinearitas dapat dideteksi pada model regresi apabila variable terdapat pasangan variabel bebas yang saling berkorelasi kuat satu sama lain.

Selanjutnya Uji Asumsi Klasik menggunakan Uji $\mathrm{T}$ adalah untuk menguji pengaruh variable bebas secara parsial atau sendiri-sendiri dengan kriteria pengujian apabila signifikan < 0,05 maka Ho ditolak, Ha diterima atau apabila signifikan > 0,05 maka Ho diterima Ha ditolak.

Ho: $\beta_{1}=0$, Artinya variabel belanja langsung (X1) tidak berpengaruh terhadap pertumbuhan ekonomi (Y) di Kabupaten Tangerang.

$\mathrm{H}_{1}: \beta_{1} \neq 0$, Artinya variabel belanja langsung (X1) berpengaruh terhadap pertumbuhan ekonomi (Y) di Kabupaten Tangerang.

Ho: $\beta_{2}=0$, Artinya variabel belanja tidak langsung (X2) tidak berpengaruh tehadap pertumbuhan ekonomi (Y) di Kabupaten Tangerang

$\mathrm{H}_{1}: \beta_{2} \neq 0$, Artinya variabel belanja tidak langsung (X2) berpengaruh terhadap pertumbuhan ekonomi (Y) di Kabupaten Tangerang

Jika tingkat signifikansi/probabilitas $\mathbf{t}$ hitung $<\mathbf{t}$ tabel atau Sig $>0,05$ maka Ho diterima dan $\mathrm{H}_{1}$ ditolak diterima, dan jika signifikansi/probabilitas $\mathbf{t}$ hitung $>\mathbf{t}$ tabel atau Sig $<0,05$ maka Ho ditolak dan $\mathrm{H}_{1}$ diterima

Kemudian dilanjutkan dengan Uji F digunakan untuk menguji tingkat signifikansi koefisien regresi variabel independen secara bersama-sama terhadap variabel dependen.

Ho : $\beta 1, \beta 2=0$ Belanja langsung (X1) dan belanja tidak langsung (X2) secara bersamasama tidak mempunyai pengaruh terhadap pertumbuhan ekonomi (Y) di Kabupaten Tangerang.

$\mathrm{H}_{1}: \beta 1, \beta 2 \neq 0$ Belanja langsung (X1) dan belanja tidak langsung (X2) secara bersamasama mempunyai pengaruh terhadap pertumbuhan ekonomi (Y) di Kabupaten Tangerang.

Jika tingkat signifikansi/probabilitas $>0,05$ maka $\mathrm{H}_{1}$ ditolak dan Ho diterima dan jika tingkat signifikansi/probabilitas $<0,05 \mathrm{maka}_{1}$ diterima dan Ho ditolak.

Selanjutnya dilakukan Uji Path Analisys (analisis jalur) uji ini digunakan untuk menjelaskan hubungan kausal empiris yaitu pola hubungan antar variabel dengan 
tujuan mengetahui pengaruh langsung maupun tidak langsung dari seperangkat variabel bebas (eksogen) terhadap variabel terikat (endogen). Yaitu pola hubungan kausal empiris variable belanja langsung (X1) dan variable belanja tidak langsung (X2) Terhadap variable Pertumbuhan ekonomi (Y) di Kabupaten Tangerang yang dirumuskan melalui persamaan struktural $\mathbf{Y}=\rho \mathbf{Y X} \mathbf{X}_{1} \mathbf{X}_{1}+\rho_{\mathbf{Y}} \mathbf{X}_{2} \mathbf{X}_{2}+\rho \mathbf{Y} \varepsilon_{1}$.

Dimana :

$\mathrm{X} 1$ = Belanja Langsung

$\mathrm{X} 2$ = Belanja Tidak langsung

$\mathrm{Y}=$ Pertumbuhan Ekonomi (PDRB)

$\rho=$ Konstanta

$\boldsymbol{\varepsilon} 1=$ Koefisien parsial masing-masing variabel

\section{HIPOTESIS PENELITIAN.}

Menurut Sugiyono (2013:59), hipotesis merupakan jawaban sementara terhadap rumusan masalah penelitian, di mana rumusan masalah penelitian telah dinyatakan dalam bentuk pertanyaan. Dikatakan sementara karena jawaban yang diberikan baru didasarkan pada teori. Hipotesis dirumuskan atas dasar kerangka pikir yang merupakan jawaban sementara atas masalah yang dirumuskan.

Hipotesis penelitian ini adalah diduga belanja daerah (belanja langsung $\mathrm{X}_{1}$ dan belanja tidak langsung $\mathrm{X}_{2}$ ) berpengaruh secara simultan dan signifikan terhadap pertumbuhan ekonomi (Y).

Kerangka hubungan kausal empiris variable $X_{1}$ dan variable $X_{2}$ Terhadap variabel $\mathrm{Y}$ dapat dirumuskan melalui persamaan struktural sebagai berikut:

$\mathrm{Y}=\rho \mathrm{YX}_{1} \mathrm{X}_{1}+\rho \mathrm{YX}_{2} \mathrm{X}_{2}+\rho \mathrm{Y}_{1}$

Dari hipotesis ini dapat dibangun model Hipotetik sebagai berikut:

Gambar 2.

Model Hipotetik

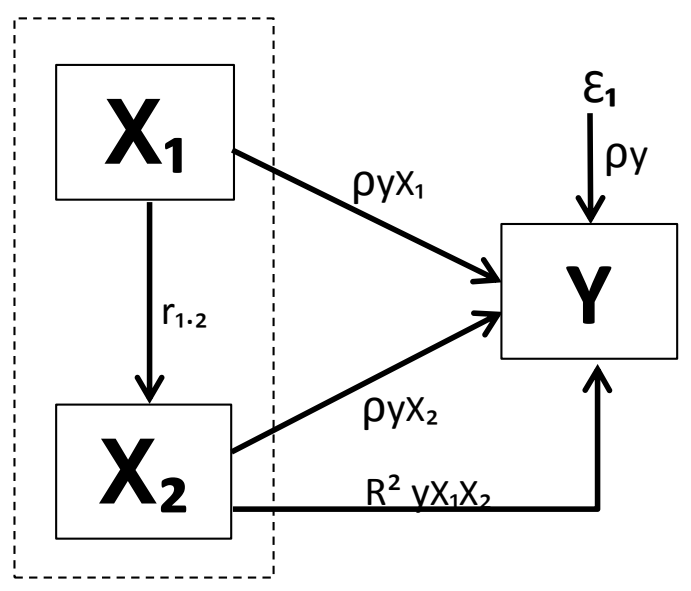


Hubungan antar variable model hipotetik dapat diajukan hipotesis penelitian yaitu :

1. Diduga ada pengaruh belanja langsung $\left(\mathrm{X}_{1}\right)$ terhadap pertumbuhan ekonomi (Y).

2. Diduga ada pengaruh belanja tidak langsung $\left(\mathrm{X}_{2}\right)$ terhadap pertumbuhan ekonomi (Y).

3. Diduga ada pengaruh secara simultan dan signifikan belanja langsung $\left(\mathrm{X}_{1}\right)$ dan belanja tidak langsung $\left(\mathrm{X}_{2}\right)$ terhadap pertumbuhan ekonomi $(\mathrm{Y})$.

Hipotesis penelitian ini dapat dijelaskan sebagai berikut:

$\mathrm{H}_{1} \mathrm{X}_{1}: \mathrm{r}=0$ : ada pengaruh belanja langsung $\left(\mathrm{X}_{1}\right)$ terhadap pertumbuhan ekonomi $(\mathrm{Y})$.

$\operatorname{HoX}_{1}: r \neq 0$ : tidak ada Pengaruh belanja langsung $\left(\mathrm{X}_{1}\right)$ terhadap pertumbuhan ekonomi $(\mathrm{Y})$.

$\mathrm{H}_{1} \mathrm{X}_{2}: \mathrm{r}=0$ : ada pengaruh belanja tidak langsung $\left(\mathrm{X}_{2}\right)$ terhadap pertumbuhan ekonomi $(\mathrm{Y})$.

$\mathrm{HoX}_{2}: \mathrm{r} \neq 0$ : tidak ada pengaruh belanja tidak langsung $\left(\mathrm{X}_{2}\right)$ terhadap pertumbuhan ekonomi (Y).

$\mathrm{H}_{1} \mathrm{X}_{1} \mathrm{X}_{2}: \mathrm{r}=0$ : ada pengaruh belanja langsung $\left(\mathrm{X}_{1}\right)$ dan belanja tidak langsung $\left(\mathrm{X}_{2}\right)$ terhadap pertumbuhan ekonomi $(\mathrm{Y})$.

$\operatorname{HoX}_{1} X_{2}: r \neq 0$ tidak ada pengaruh belanja langsung $\left(X_{1}\right)$ dan belanja tidak langsung $\left(X_{2}\right)$ terhadap pertumbuhan ekonomi $(\mathrm{Y})$.

\section{HASIL PENELITIAN DAN PEMBAHASAN}

\section{1) Hasil Penelitian.}

Berdasarkan Peraturan Daerah Kabupaten Tangerang Nomor 2 Tahun 2009 tentang Pokok-Pokok Pengelolaan Keuangan Daerah pasal 26 menyebutkan belanja daerah dipergunakan dalam rangka pelaksanaan urusan pemerintahan yang menjadi kewenangan daerah yang terdiri dari belanja penyelenggaraan urusan wajib, belanja penyelenggaan urusan pilihan dan belanja penyelenggaam urusan yang dilaksanakan bersama antara pemerintah dan pemerintah daerah atau dengan pemerintah daerah lain. Sedangkan pada pasal 27 menyatakann belanja daerah diklasifikasikan menurut organisasi, fungsi, program dan kegiatan, serta jenis belanja. Klasifikasi menurut jenis belanja dikelompokkan menjadi belanja langsung dan belanja tidak langsung. Realisasi belanja daerah kabupaten Tangerang tahun 2008 - 2014 yang dikelompokkan kedalam belanja langsung dan belanja tidak langsung dapat dilihat pada tabel 8 berikut ini :

Tabel 4

Proporsi Belanja Daerah Kabupaten Tangerang Tahun 2008 - 2014

\begin{tabular}{|c|c|c|c|c|c|c|c|}
\hline \multirow{2}{*}{ No } & \multirow{2}{*}{ Tahun } & \multicolumn{6}{|c|}{ Belanja Daerah (000.Rp) } \\
\hline & & Total Belanja & $(\%)$ & Belanja Langsung & $(\%)$ & $\begin{array}{c}\text { Belanja Tidak } \\
\text { Langsung }\end{array}$ & $(\%)$ \\
\hline 1 & 2008 & $1,690,387,008$ & 100 & $950,172,541$ & 56.21 & $740,214,467$ & 43.79 \\
\hline 2 & 2009 & $2,015,224,698$ & 100 & $1,155,409,218$ & 57.33 & $859,815,480$ & 42.67 \\
\hline 3 & 2010 & $1,783,508,770$ & 100 & $943,139,600$ & 52.88 & $840,369,170$ & 47.12 \\
\hline 4 & 2011 & $2,027,969,594$ & 100 & $1,113,208,712$ & 54.89 & $914,761,028$ & 45.11 \\
\hline 5 & 2012 & $2,556,468,594$ & 100 & $1,427,126,209$ & 55.82 & $1,129,342,384$ & 44.18 \\
\hline 6 & 2013 & $2,871,204,506$ & 100 & $1,696,486,655$ & 59.09 & $1,174,717,851$ & 40.91 \\
\hline 7 & 2014 & $3,512,771,525$ & 100 & $2,245,622,940$ & 63.93 & $1,267,148,584$ & 36.07 \\
\hline
\end{tabular}

Sumber : LRA BPKAD Kab Tangerang 2008-2014. 
Realisasi belanja daerah kabupaten Tangerang tahun 2008 sampai dengan tahun 2014 setiap tahunnya rata-rata mengalami kenaikan sebesar 13,69\%. Realisasi belanja daerah tahun 2008 sebesar Rp. 1,690,387,008,000,-, total belanja daerah tahun 2009 sebesar Rp. 2,015,224,698,000,-, total belanja daerah tahun 2010 sebesar Rp. 1,783,508,770,000,-, total belanja daerah tahun 2011 sebesar Rp. 2,027,969,594,000,-. total belanja daerah tahun 2012 sebesar Rp. 2,556,468,594,000,- total belanja daerah tahun 2013 sebesar Rp. 2,871,204,506,000,- dan total belanja daerah tahun 2014 sebesar Rp. 3,512,771,525,000,-. Belanja daerah kabupaten Tangerang terendah terjadi pada tahun 2010 yakni mengalami penurunan sebesar $11 \%$ dari tahun 2009 .

Proporsi belanja langsung terhadap total belanja kabupaten Tangerang tahun 2008 sebesar 56,21\%, tahun 2009 sebesar 57,33, tahun 2010 sebesar 52,88\%, tahun 2011 sebesar 54,89\%, pada tahun 2012 sebesar 55,82\%, pada tahun 2013 sebesar 59,09 dan pada tahun 2014 sebesar 63,93\%. sedangkan proporsi belanja tidak langsung terhadap total belanja pada tahun 2008 sebesar 43,79\%, pada tahun 2009 sebesar 42,67 $\%$, pada tahun 2010 sebesar $47,12 \%$, pada tahun 2011 sebesar $45,11 \%$, pada tahun 2012 sebesar 44,18 \%, pada tahun 2013 sebesar 40,1\%. dan pada tahun 2014 sebesar $36,07 \%$.

Belanja langsung adalah belanja yang dianggarkan terkait secara langsung dengan pelaksanaan program dan kegiatan. Kelompok belanja langsung dibagi menurut jenis belanja yang terdiri dari belanja pegawai, belanja barang dan jasa, dan belanja modal. Realisasi belanja langsung kabupaten Tangerang dapat dilihat pada tabel 9 sebagai berikut :

Tabel 5.

Realisasi Belanja Langsung Kabupaten Tangerang 2008 - 2014

\begin{tabular}{|c|c|r|r|}
\hline No & Tahun & Realisasi Belanja Langsung (000.Rp) & (\%) \\
\hline 1 & 2008 & $950,172,541$ & \\
\hline 2 & 2009 & $1,155,409,218$ & 17.76 \\
\hline 3 & 2010 & $943,139,600$ & -22.51 \\
\hline 4 & 2011 & $1,113,208,712$ & 15.28 \\
\hline 5 & 2012 & $1,427,126,209$ & 22.00 \\
\hline 6 & 2013 & $1,696,486,655$ & 15.88 \\
\hline 7 & 2014 & $2,245,622,940$ & 24.45 \\
\hline
\end{tabular}

Sumber: LRA BPKAD Kab Tangerang 2008-2014.

Realisasi belanja langsung Kabupaten Tangerang Tahun 2008 sebesar Rp. 950.172.541.000,-, kemudian belanja langsung tahun 2009 sebesar Rp. 1.155.409.218.000,- atau naik sebesar 17,76 \% dari belanja tahun 2008. Belanja langsung kabupaten Tangerang tahun 2010 mengalami penurunan sebesar $(-22.51 \%)$ atau sebesar Rp. 943.139.600.000,- bila dibandingkan tahun 2009. Selanjutnya realisasi belanja langsung tahun 2011 sebesar Rp. 1.113.208.712.000,- atau naik sebesar 15,28\% disbanding tahun 2010. Kemudian realisasi belanja langsung tahun 2012 meningkat sebesar $22 \%$ menjadi RP. 1.427.126.209.000,- . sedangkan realisasi belanja langsung pada tahun 2013 meningkat sebesar 15,88 \% menjadi Rp. 1.696.486.655.000,- dan pada tahun 2014 realisasi belanja langsung Kabupaten Tangerang meningkat sebesar 24,45 \% menjadi Rp. 2.245.622.940.000,-. 
Belanja tidak langsung merupakan belanja yang dianggarkan tidak terkait secara langsung dengan pelaksanaan program dan kegiatan. Kelompok belanja tidak langsung dibagi menurut jenis belanja yang terdiri dari belanja pegawai, belanja bunga, belanja subsidi, hibah, belanja bantuan sosial, belanja bagi hasil, belanja bantuan keuangan dan belanja tidak terduga. Realisasi belanja langsung kabupaten Tangerang dapat dilihat pada tabel 10 sebagai berikut :

Tabel 6.

Realisasi Belanja Tidak Langsung Kabupaten Tangerang 2008 - 2014

\begin{tabular}{|c|c|r|c|}
\hline No & Tahun & Realisasi Belanja Tidak Langsung (000.Rp) & (\%) \\
\hline 1 & 2008 & $740,214,467$ & \\
\hline 2 & 2009 & $859,815,480$ & 13.91 \\
\hline 3 & 2010 & $840,369,170$ & -2.31 \\
\hline 4 & 2011 & $914,761,028$ & 8.13 \\
\hline 5 & 2012 & $1,129,342,384$ & 19.00 \\
\hline 6 & 2013 & $1,174,717,851$ & 3.86 \\
\hline 7 & 2014 & $1,267,148,584$ & 7.29 \\
\hline
\end{tabular}

Sumber : LRA BPKAD Kab Tangerang 2008-2014

Realisasi belanja tidak langsung Kabupaten Tangerang Tahun 2008 sebesar Rp. 740.214.467.000,- atau sebesar $43 \%$ dari total belanja tahun 2008. Belanja tidak langsung tahun 2009 sebesar Rp 859.815.480.000,- atau meningkat sebesar 13,91\%, sedangkan belanja tidak langsung tahun 2010 mengalami penurunan sebesar $(-2,31 \%)$ atau sebesar Rp. 840.369.170.000,- bila dibandingkan tahun 2009, hal ini karena terjadinya pemekaran sebagian wilayah kabupaten Tangerang menjadi wilayah Kota Tangerang Selatan. Kemudian tahun 2011 belanja tidak langsung kabupaten mengalami kenaikan sebesar 8,13\% atau menjadi Rp. 914.761.028.000,-. Selanjutnya tahun 2012 meningkat lagi sebesar $19 \%$ menjadi Rp. 1.129.342.384.000,-. Kemudian tahun 2013 meningkat sebesar 3,86 \% menjadi Rp.1.174.717.851.000,- dan tahun 2014 meningkat sebesar 7,29 \% menjadi RP. 1.267.148.584.000,-.

Secara umum Produk Domestik Regional Bruto (PDRB) Kabupaten Tangerang dari tahun 2008-2013 terus menerus mengalami kenaikan. Hal ini dapat dilihat pada besaran PDRB atas dasar harga konstan tahun 2008 sebesar Rp. 16.647.358.000,-, tahun 2009 sebesar Rp. 17.382.091.000,-, tahun 2010 sebesar Rp. 18.483.033.000,tahun 2011 sebesar Rp. 19.664.496.000,-, tahun 2012 sebesar Rp. 20.804.088.000,- dan tahun 2013 sebesar Rp. 22.074.241.000,-. Sedangkan besaran PDRB atas dasar harga berlaku tahun 2008 sebesar Rp. 28.437.349.000,-, tahun 2009 sebesar Rp. 30.884.648.000,-, tahun 2010 sebesar Rp. 34.866.222.000,-, tahun 2011 sebesar Rp. 39.357.074.000,-, tahun 2012 sebesar Rp. 44.148.610.000,-, dan tahun 2013 sebesar Rp. 50.939.877.000,-- 
Tabel 7.

Produk Domestik Regional Bruto Kabupaten Tangerang tahun 2008-2014

\begin{tabular}{|c|c|r|r|}
\hline \multirow{2}{*}{ No } & \multirow{2}{*}{ Tahun } & \multicolumn{2}{|c|}{ Produk Domestik Regional Bruto (000.Rp) } \\
\cline { 3 - 4 } & & Atas Dasar Harga Konstan 2000 & Atas Dasar Harga Berlaku \\
& & $16,647,358.000$ & 2000 \\
\hline 1 & 2008 & $17,382,091.000$ & $28,437,349.000$ \\
\hline 2 & 2009 & $18,483,033.000$ & $30,884,648.000$ \\
\hline 3 & 2010 & $19,664,496.000$ & $34,866,222.000$ \\
\hline 4 & 2011 & $20,804,088.000$ & $39,357,074.000$ \\
\hline 5 & 2012 & $22,074,241.000$ & $44,148,610.000$ \\
\hline 6 & 2013 & $23,159,090.020$ & $50,939,877.000$ \\
\hline 7 & 2014 & & $56,536,641.286$ \\
\hline
\end{tabular}

Sumber : BPS Kab Tangerang 2008-2014

\section{2) Pembahasan.}

\section{a. Uji Normalitas Data}

Uji normalitas data metode Kolmogorov-Smirnov Test antara variable belanja langsung, variable belanja tidak langsung terhadap Produk Domestik Regional Bruto di kabupaten Tangerang dapat dilihat pada tabel 8 berikut ini:

Tabel 8

One-Sample Kolmogorov-Smirnov Test

\begin{tabular}{|ll|r|r|r|}
\hline & & $\begin{array}{c}\text { Belanja Langsung } \\
(\mathrm{X} 1)\end{array}$ & $\begin{array}{c}\text { Belanja Tdk } \\
\text { Langsung (X2) }\end{array}$ & PDRB ADHB (Y) \\
\hline N & & 7 & 7 & 7 \\
Normal Parametersa,b & Mean & 1361595125.00 & 989481280.57 & 40738631.612286 \\
& Std. Deviation & 473732316.287 & 199055079.697 & 10409025.8329399 \\
Most Extreme Differences & Absolute & .240 & .218 & .142 \\
& Positive & .240 & .218 & .142 \\
& Negative & -.189 & -.187 & -.122 \\
Kolmogorov-Smirnov Z & & .634 & .576 & .376 \\
Asymp. Sig. (2-tailed) & & .816 & .894 & .999 \\
\hline
\end{tabular}

a. Test distribution is Normal.

b. Calculated from data.

Hasil Uji Normalitas Kolmogorov-Smirnov menunjukkan bahwa nilai uji Kolmogorov-Smirnov belanja langsung adalah 0.634, nilai uji Kolmogorov-Smirnov belanja tidak langsung adalah 0.576 dan nilai uji Kolmogorov-Smirnov Produk Domestik Regional Bruto adalah 0.376. Nilai uji masing-masing variable tersebut lebih besar dari 0,05 sehingga dapat diartikan bahwa data yang dipakai dalam penelitian ini adalah terdistribusi normal.

Hasil uji One-Sample t Test variable belanja langsung dan variable belanja tidak langsung terhadap Produk Domestik Regional Bruto dapat dilihat pada tabel 14 sebagai berikut: 
Tabel 9

One-Sample Statistics

\begin{tabular}{|l|r|r|r|r|}
\hline & N & \multicolumn{1}{|c|}{ Mean } & \multicolumn{1}{c|}{ Std. Deviation } & \multicolumn{1}{c|}{ Std. Error Mean } \\
\hline Belanja Langsung (X1) & 7 & 1361595125.00 & 473732316.287 & 179053985.273 \\
\hline Belanja Tdk Langsung (X2) & 7 & 989481280.57 & 199055079.697 & 75235748.297 \\
\hline PDRB ADHB (Y) & 7 & 40738631.612286 & 10409025.8329399 & 3934241.9634866 \\
\hline
\end{tabular}

Tabel 10

One-Sample Test

\begin{tabular}{|c|c|c|c|c|c|c|}
\hline & \multicolumn{6}{|c|}{ Test Value $=0$} \\
\hline & & & & & $\begin{array}{r}\text { 95\% Confidence } \\
\text { Differe }\end{array}$ & $\begin{array}{l}\text { Interval of the } \\
\text { cce }\end{array}$ \\
\hline & $\mathrm{t}$ & $\mathrm{df}$ & $\begin{array}{l}\text { Sig. }(2- \\
\text { tailed) }\end{array}$ & Mean Difference & Lower & Upper \\
\hline Belanja Langsung (X1) & 7.604 & 6 & .000 & 1361595125.000 & 923465806.44 & 1799724443.56 \\
\hline Belanja Tdk Langsung (X2) & 13.152 & 6 & .000 & 989481280.571 & 805386036.43 & 1173576524.71 \\
\hline PDRB ADHB (Y) & 10.355 & 6 & .000 & 40738631.6122857 & 31111888.326559 & 50365374.898012 \\
\hline
\end{tabular}

Pada tabel 10 One-Sample Test menunjukkan nilai statistic t belanja langsung $\left(\mathrm{X}_{1}\right)$ sebesar 7,604 (nilai $\mathrm{t}$ hitung $\left.=7,604\right)$; $\mathrm{df}$ (degree $\mathrm{pf}$ freedom) $=6$ (derajat kebebasan $=6)$; Sig (2-tailed) $=0.000$, kemudian nilai statistic $\mathrm{t}$ belanja tidak langsung $\left(\mathrm{X}_{2}\right)$ sebesar 13,152 (nilai $\mathrm{t}$ hitung $\left.=13,152\right)$; df (degree pf freedom) $=6$ (derajat kebebasan $=6$ ); Sig (2-tailed) $=0.000$, dan selanjutnya nilai statistic t Produk Domestik Regional Bruto sebesar 10,355 (nilai t hitung $=10,355)$; df (degree pf freedom) $=6$ $($ derajat kebebasan $=6) ; \operatorname{Sig}(2$-tailed $)=0.000$, dan $\mathrm{t}$ tabel $=2,015$

Hasil One-Sample Test menunjukkan bahwa nilai t hitung $X_{1}=7,604, X_{2}=$ $13,152, Y=10,355, T$ tabel $=2,015$, dan nilai Sig $X_{1}=0,000, \operatorname{Sig} X_{2}=0,000, \operatorname{Sig} Y=$ 0,000. Karena nilai $\mathbf{t}$ hitung $X_{1}, X_{2}, Y$ lebih besar (>) dari t tabel, dan nilai Sig $X_{1}, X_{2}, Y$ lebih kecil dari $\alpha$ 0,05 maka Ho ditolak dan $\mathrm{H}_{1}$ diterima. Hal ini diartikan bahwa data yang dipakai dalam penelitian adalah signifikan sehingga dapat dilanjutkan pada uji selanjutnya.

\section{b. Uji T.}

Hasil uji signifikansi secara individual dengan menggunakan SPSS 17 dapat dilihat pada tabel dibawah ini:

Tabel 11

Coefficients $^{\mathrm{a}}$

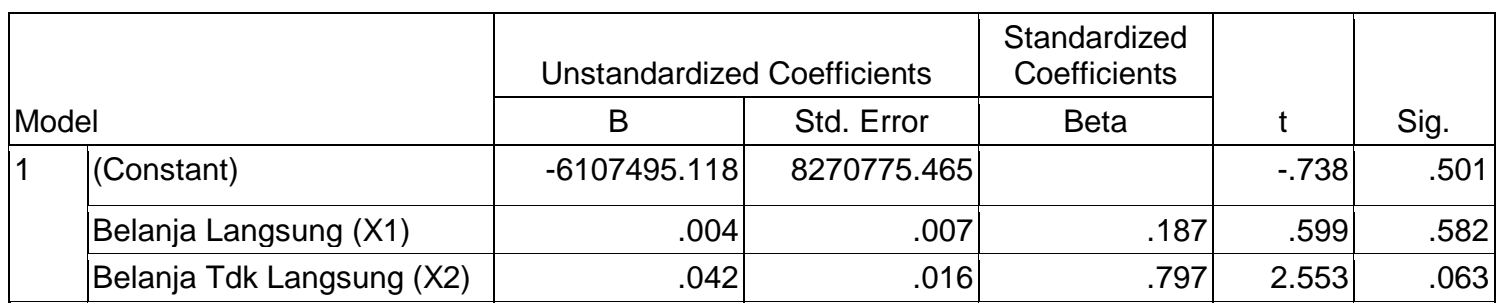

a. Dependent Variable: PDRB ADHB (Y) 
Uji signifikansi secara individual ditunjukkan oleh tabel 11 Coefficients $^{\mathrm{a}}$ sebagai berikut :

1. Pengaruh $\left(\mathrm{X}_{1}\right)$ terhadap $(\mathrm{Y})$ : pada tabel 11 Coefficients $^{\mathrm{a}}$ didapat nilai Sig belanja langsung $\left(\mathrm{X}_{1}\right)$ sebesar 0,582, nilai Sig 0,852 lebih besar dari nilai $\alpha=0,05(0,852>$ $0,05)$, dan $\mathbf{t}$ hitung adalah 0,599 lebih kecil dari t tabel 2,131 $(0,599<2,131)$ maka hipotesis penelitian adalah Ho diterima dan $\mathrm{H}_{1}$ ditolak artinya koefisien analisis jalur adalah tidak signifikan. Dengan demikian hipotesis kalimatnya adalah: Belanja langsung $\left(\mathrm{X}_{1}\right)$ tidak berpengaruh terhadap Produk Domestik Regional Bruto (Y).

2. Pengaruh $\left(\mathrm{X}_{2}\right)$ terhadap $(\mathrm{Y})$ : pada tabel 11 Coefficients $^{\mathrm{a}}$ didapat nilai Sig belanja tidak langsung sebesar 0,063 , nilai Sig 0,063 lebih besar dari nilai probabilitas 0,05 $(0,063>0,05)$, dan $\mathbf{t}$ hitung adalah 2,553 lebih kecil dari $\mathrm{t}$ tabel 2,776 (2,553 < 2,776) maka hipotesis penelitian adalah Ho diterima dan $\mathrm{H}_{1}$ ditolak artinya koefisien analisis jalur adalah tidak signifikan. Dengan demikian hipotesis kalimatnya adalah: Belanja Tidak Langsung $\left(\mathrm{X}_{2}\right)$ tidak berkontribusi terhadap Produk Domestik Regional Bruto (Y).

\section{c. Uji F.}

Uji $\mathrm{F}$ digunakan untuk mengetahui apakah variabel-variabel independen secara simultan berpengaruh signifikan terhadap variabel dependen. Derajat kepercayaan yang digunakan adalah 0,05. Apabila nilai $\mathrm{F}$ hasil perhitungan lebih besar daripada nilai $\mathrm{F}$ menurut tabel maka hipotesis alternatif, yang menyatakan bahwa semua variabel independen secara simultan berpengaruh signifikan terhadap variabel dependen. Untuk analisisnya dari output SPSS dapat dilihat dari tabel Anova sebagai berikut:

\begin{tabular}{|c|c|c|c|c|c|}
\hline \multirow[b]{2}{*}{ Model } & \multicolumn{3}{|c|}{$\begin{array}{l}\text { Tabel } 12 \\
\text { ANOVA }^{\mathrm{b}}\end{array}$} & \multirow[b]{2}{*}{$F$} & \multirow[b]{2}{*}{ Sig. } \\
\hline & Sum of Squares & $\mathrm{df}$ & Mean Square & & \\
\hline Regression & 616428327950247.400 & 2 & 308214163975123.700 & 36.628 & $.003^{a}$ \\
\hline Residual & 33658584794611.840 & 4 & 8414646198652.960 & & \\
\hline Total & 650086912744859.200 & 6 & & & \\
\hline
\end{tabular}

a. Predictors: (Constant), Belanja Tdk Langsung (X2), Belanja Langsung (X1)

b. Dependent Variable: PDRB ADHB (Y)

Pada output anova menjelaskan ada pengaruh secara simultan dan signifikan variable bebas belanja langsung $\left(\mathrm{X}_{1}\right)$ dan belanja tidak langsung $\left(\mathrm{X}_{2}\right)$ terhadap variable terikat PDRB (Y). dari tabel diatas terlihat bahwa $\mathrm{F}$ hitung 36,628 > F tabel 6,94 dengan signifikansi/ Sig $0.003<$ dari 0.05 maka $\mathrm{H}_{1}$ diterima dan Ho ditolak, artinya bahwa belanja langsung $\left(\mathrm{X}_{1}\right)$ dan belanja tidak langsung $\left(\mathrm{X}_{2}\right)$ berpengaruh secara simultan dan signifikan terhadap produk domestic regional bruto $(\mathrm{Y})$.

\section{d. Uji Path Analysis}

David Garson dari North Carolina State University mendefinisikan analisis jalur sebagai "Model perluasan regresi yang digunakan untuk menguji keselarasan matriks korelasi dengan dua atau lebih model hubungan sebab akibat yang dibandingkan oleh peneliti. Model jalur digambarkan dalam bentuk gambar lingkaran dan panah dimana anak panah tunggal menunjukkan sebagai penyebab. Regresi dikenakan pada masing- 
masing variable dalam suatu model sebagai variabel tergantung (pemberi respon) sedang yang lain sebagai penyebab. Pembobotan regresi diprediksikan dalam suatu model yang dibandingkan dengan matriks korelasi yang di observasi untuk semua variabel dan dilakukan juga penghitungan uji keselarasan statistik. (David Garson, 2003).

Persamaan structural hipotesis adalah $\mathrm{Y}=\rho \mathrm{yx}_{1}+\rho \mathrm{yx}_{2}+\rho \mathrm{y} \varepsilon_{1} \operatorname{dimana}\left(\mathrm{X}_{1}\right)$ Belanja Langsung ; $\left(\mathrm{X}_{2}\right)$ Belanja Tidak Langsung dan Y Produk Domestik Regional Bruto (PDRB).

Tabel 13

Model Summary

\begin{tabular}{|c|c|c|c|c|c|c|c|c|c|}
\hline \multirow[b]{2}{*}{ Model } & \multirow[b]{2}{*}{$\mathrm{R}$} & \multirow[b]{2}{*}{$\begin{array}{c}\mathrm{R} \\
\text { Square }\end{array}$} & \multirow[b]{2}{*}{$\begin{array}{l}\text { Adjusted } \\
\text { R Square }\end{array}$} & \multirow[b]{2}{*}{$\begin{array}{c}\text { Std. Error of the } \\
\text { Estimate }\end{array}$} & \multicolumn{5}{|c|}{ Change Statistics } \\
\hline & & & & & $\begin{array}{l}\text { R Square } \\
\text { Change }\end{array}$ & $\begin{array}{c}\mathrm{F} \\
\text { Change }\end{array}$ & df1 & $\mathrm{df2}$ & $\begin{array}{l}\text { Sig. F } \\
\text { Change }\end{array}$ \\
\hline & $974^{a}$ & .948 & .922 & 2900800.9581240 & .948 & 36.628 & 2 & 4 & .003 \\
\hline
\end{tabular}

Secara simultan belanja langsung dan belanja tidak langsung berpengaruh positif dan signifikan terhadap Produk Domestik Regional Bruto (PDRB). Besaran pengaruh simultan adalah $\mathrm{R}$ Square 0,948 atau dibulatkan menjadi $95 \%$ merupakan kontribusi dari variabel Belanja langsung dan belanja tidak langsung terhadap Produk Domestik Regional Bruto (PDRB). Sedangkan sisanya $5 \%$ dipengaruhi oleh faktor lain.

Tabel 14

ANOVA $^{\mathrm{b}}$

\begin{tabular}{|r|l|r|r|r|r|c|}
\hline \multicolumn{2}{|c|}{ Model } & \multicolumn{1}{c|}{ Sum of Squares } & \multicolumn{1}{c|}{ df } & Mean Square & F & Sig. \\
\hline 1 & Regression & 616428327950247.400 & 2 & 308214163975123.700 & 36.628 & $.003^{\mathrm{a}}$ \\
\cline { 2 - 8 } & Residual & 33658584794611.840 & 4 & 8414646198652.960 & & \\
\cline { 2 - 8 } & Total & 650086912744859.200 & 6 & & & \\
\hline
\end{tabular}

a. Predictors: (Constant), Belanja Tdk Langsung (X2), Belanja Langsung (X1)

b. Dependent Variable: PDRB ADHB (Y)

Tabel 15

Coefficients $^{\mathrm{a}}$

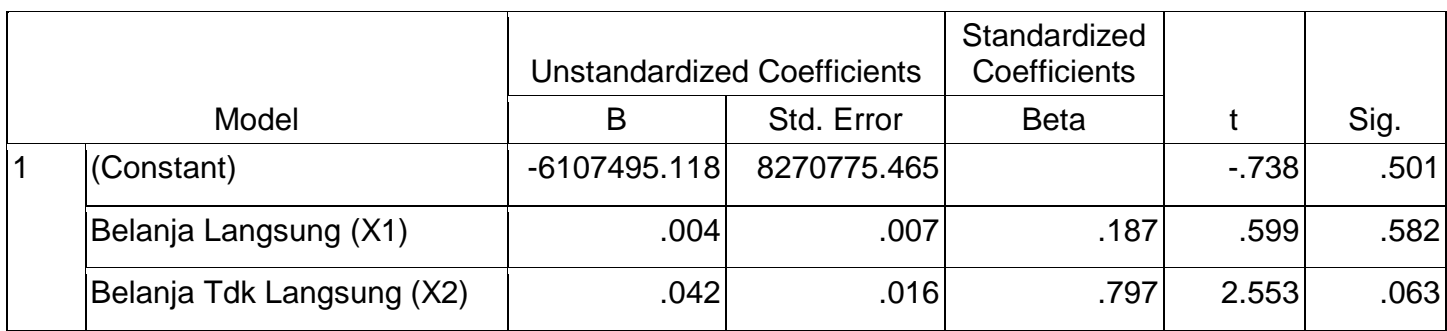

a. Dependent Variable: PDRB ADHB $(Y)$

Hubungan antar variabel belanja langsung $X_{1}$ dan belanja tidak langsung $X_{2}$ terhadap PDRB (Y) terjadi secara simultan dan signifikan. Hal ini dapat dilihat pada tabel anova bahwa nilai (sig) $0.003<0,05$. Pengujian signifikansi lebih lanjut diteruskan dengan pengujian individual melalui parameter statistik t. Hasil pengujian individual menunjukkan tidak ada pengaruh yang signifikan. Dengan memperhatikan 
perolehan sig $>0,05$ pada jalur $\mathrm{X}_{1}$, dan sig $>0,05$ pada jalur $\mathrm{X}_{2}$. Hal ini tentunya menjelaskan bahwa secara parsial belanja langsung dan belanja tidak langsung dapat dijadikan variabel yang berpengaruh terhadap Produk Domestik Regional Bruto (PDRB). Lebih lanjut pengaruh kausal empiris digambarkan melalui persamaan:

$$
\begin{aligned}
& Y=\rho \mathrm{yx}_{1}+\rho \mathrm{yx}_{2}+\rho y \varepsilon_{1} \text { atau} \\
& Y=0,187 \mathrm{X}_{1}+0,797 \mathrm{X}_{2}+(1-0,948) \varepsilon_{1} \\
& Y=0,187 \mathrm{X}_{1}+0,797 \mathrm{X}_{2}+0,052 \varepsilon_{1} .
\end{aligned}
$$

Seraca parsial belanja langsung tidak signifikan memiliki pengaruh terhadap Produk Domestik Regional Bruto (PDRB), besarnya pengaruh parsial dan langsung belanja langsung $\left(\mathrm{X}_{1}\right)$ terhadap Produk Domestik Regional Bruto $(\mathrm{Y})$ adalah 0,187 atau $\mathbf{1 8 , 7 \%}$ sisanya $81,3 \%$ dipengaruhi oleh faktor lain.

Secara parsial belanja tidak langsung $\left(\mathrm{X}_{2}\right)$ tidak signifikan memiliki pengaruh terhadap Produk Domestik Regional Bruto (Y), besarnya pengaruh langsung secara parsial belanja tidak langsung $\left(\mathrm{X}_{2}\right)$ terhadap Produk Domestik Regional Bruto (Y) adalah 0,797 atau $\mathbf{7 9 , 7} \%$ sisanya $20,3 \%$ dipengaruhi oleh faktor lain.

Diagram jalur hubungan kausal empiris Belanja Langsung $\left(\mathrm{X}_{1}\right)$ dan Belanja Tidak Langsung $\left(\mathrm{X}_{2}\right)$ Terhadap Produk Domestik Regional Bruto (Y) dapat dilihat pada gambar dibawah ini:

\section{Gambar. 5}

\section{Diagram Jalur Hubungan Kausal Empiris}

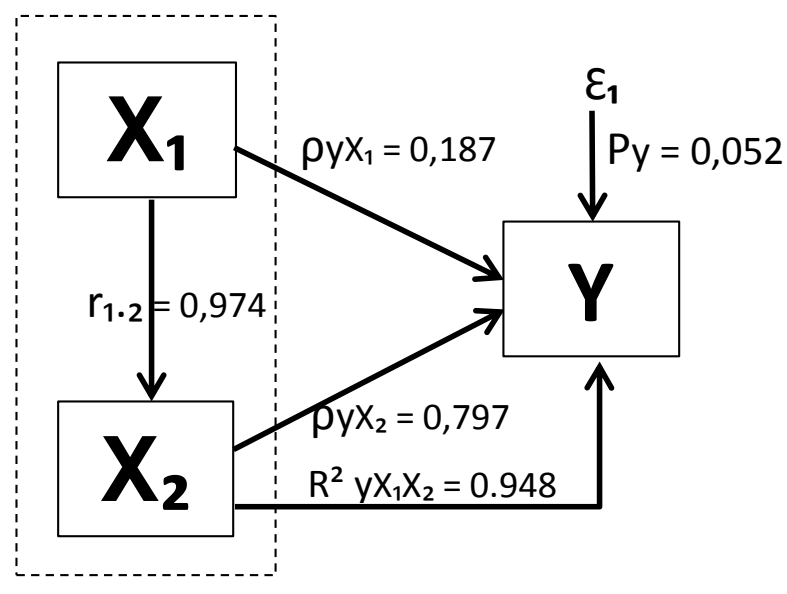

Pengaruh langsung melalui hubungan korelatif kausal empiris belanja langsung $\left(\mathrm{X}_{1}\right)$ yang secara langsung mempengaruhi belanja tidak langsung $\left(\mathrm{X}_{2}\right)$ adalah $; \mathrm{r}_{12}=$ sebesar $0,974^{2}=0,949$ atau sebesar $94,9 \%$ dan sisanya $5,1 \%$ dipengaruhi faktor lain.

Pengaruh langsung melalui hubungan korelatif kausal empiris belanja langsung $\left(\mathrm{X}_{1}\right)$ yang secara langsung mempengaruhi produk domestik regional bruto $(\mathrm{Y})$ adalah ; $\operatorname{\rho yx}_{1}$ sebesar $0,187^{2}=0,035$ atau sebesar $03,5 \%$ dan sisanya $96,5 \%$ dipengaruhi oleh faktor lain. 
Pengaruh langsung melalui hubungan korelatif kausal empiris belanja tidak langsung $\left(\mathrm{X}_{2}\right)$ yang secara langsung mempengaruhi produk domestik regional bruto $(\mathrm{Y})$ adalah; $\rho \mathrm{yx}_{2}$ sebesar $0,797^{2}=0,63$ atau sebesar $63 \%$ dan sisanya $37 \%$ dipengaruhi oleh faktor lain.

Pengaruh langsung melalui hubungan korelatif kausal empiris belanja langsung $\left(\mathrm{X}_{1}\right)$ dan belanja tidak langsung $\left(\mathrm{X}_{2}\right)$ yang secara bersama-sama dan langsung mempengaruhi produk domestik regional bruto (Y) adalah; $\mathrm{R}^{2} \mathrm{yx}_{1} \mathrm{x}_{2}$ sebesar $0,948^{2}$ $=0,899$ atau sebesar $89,9 \%$ dan sisanya sebesar $10,1 \%$ dipengaruhi oleh faktor lain.

Tabel 16

Rekapitulasi Hubungan Kausal Empirs

\begin{tabular}{|l|c|l|c|c|}
\hline \multirow{2}{*}{ Pengaruh Variabel } & \multicolumn{2}{|c|}{ Pengaruh Kausal Empiris } & \multirow{2}{*}{$\begin{array}{c}\text { Sisa } \\
\text { Tidak Langsung }\end{array}$} & \multirow{2}{*}{ Total } \\
\cline { 2 - 3 } & Langsung & Melalui $Y$ & $\varepsilon_{1}$ & \\
\hline $\mathrm{X}_{1}$ terhadap $\mathrm{X}_{2}$ & 0,949 & & 0.051 & 0,949 \\
\hline $\mathrm{X}_{1}$ Terhadap Y & 0,035 & & 0.965 & 0,035 \\
\hline $\mathrm{X}_{2}$ Terhadap Y & 0,899 & & 0.101 & 0,899 \\
\hline $\mathrm{X}_{1}, \mathrm{X}_{2}$ Terhadap Y & 0,948 & & 0.052 & 1.00 \\
\hline
\end{tabular}

Gambar 6

Grafik Regression Standardized Residual

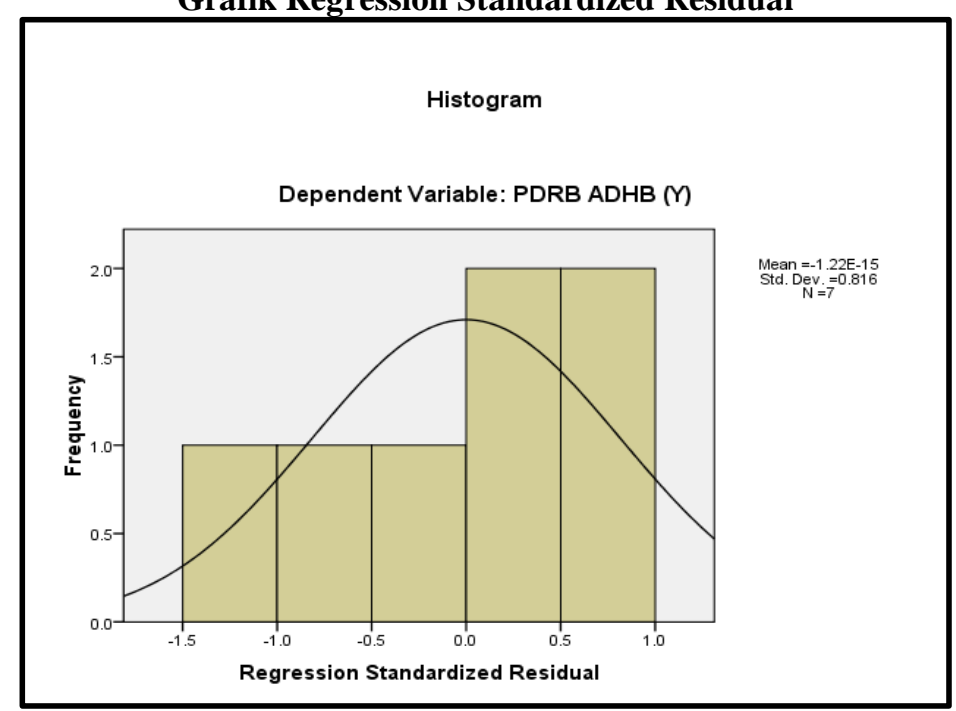

Grafik diatas berbentuk kurva melengkung yang menggambarkan bahwa data yang digunakan untuk penelitian terdistribusi normal dan menjelaskan adanya korelasi hubungan antar variable. 


\section{Gambar 7 \\ Grafik Normal P-P Plot Regression Standardized Residual}

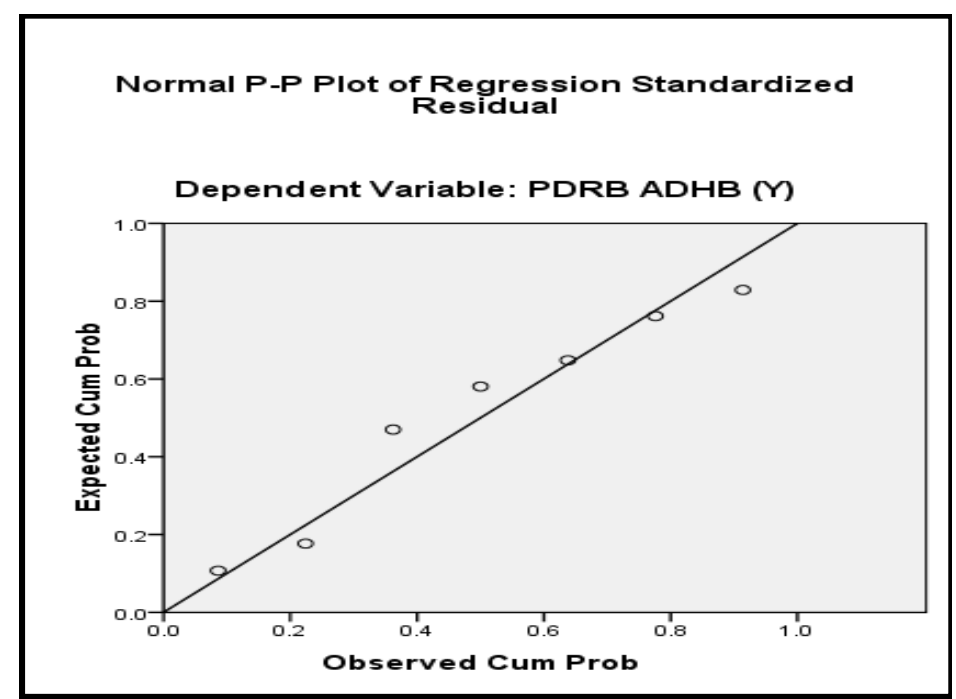

Grafik diatas menjelaskan bahwa model regressi yang diperoleh terdisitribusi normal, hal ini dapat dilihat pada grafik Normal P-P Plot diatas bahwa posisi sebaran data yang ditunjukkan oleh titik-titik berada disekitar garis diagonal.

Gambar 9

Grafik Scatterplot 2

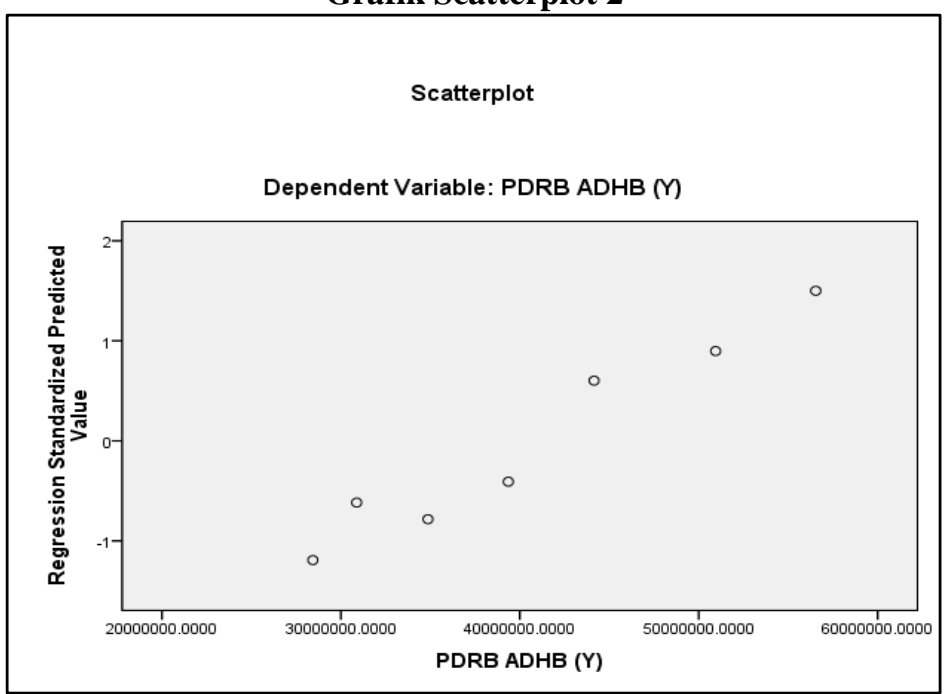

Grafik diatas menggambarkan data yang digunakan dalam penelitian ini memiliki keajegan atau terdistribusi normal. 


\section{E. KESIMPULAN}

Berdasarkan analisis data dan pembahasan dalam penelitian ini maka dapat dirumuskan kesimpulan hasil penelitian analisis pengaruh belanja langsung dan belanja tidak langsung terhadap pertumbuhan ekonomi di kabupaten Tangerang tahun 2008 2014 sebagai berikut:

1) Tidak cukup bukti terdapat pengaruh belanja langsung terhadap pertumbuhan ekonomi di kabupaten Tangerang.

2) Tidak cukup bukti terdapat pengaruh belanja tidak langsung terhadap pertumbuhan ekonomi di kabupaten Tangerang.

3) Terbukti terdapat pengaruh belanja daerah (belanja langsung dan belanja tidak langsung) terhadap pertumbuhan ekonomi di kabupaten Tangerang

\section{F. SARAN}

Berdasarkan pada kesimpulan, saran-saran yang dapat disampaikan adalah sebagai berikut :

1) Dikarenakan nilai konstan negative, maka untuk mencapai nilai pertumbuhan ekonomi sebesar 0 pemerintah Kabupaten Tangerang harus menutup defisit nilai konstan sebesar Rp. 132.771.632.99,-- sehingga nilai konstan menjadi positif .

2) Untuk meningkatkann nilai pertumbuhan ekonomi sebesar 1 digit disarankan agar pemerintah Kabupaten Tangerang mengalokasikan anggaran belanja daerah senilai Rp. 6.107.495,12,--.

3) Untuk meningkatkan pertumbuhan ekonomi, pemerintah kabupaten Tangerang harus melakukan evaluasi secara menyeluruh dan berkelanjutan terhadap sistem tata kelola belanja daerah melalui program-program yang efektif guna mendorong masyarakat dalam rangka meningkatkan produktifitas daerah.

4) Oleh karena keterbatasan data dan waktu dalam penelitian ini, disarankan kepada peneliti berikutnya untuk menambah sampel penelitian sehingga dapat mencerminkan kondisi yang sebenarnya dan dapat mengetahui alokasi belanja daerah yang dominan berpengaruh terhadap pertumbuhan ekonomi. 


\section{DAFTAR PUSTAKA:}

Mudrajad.Kuncoro 2010. Ekonomi Pembangunan, Teori Masalah dan. Kebijakan, LP3ES Jakarta.

Musgrave, Richard A and Peggy B 2010 Pengelolaan Anggaran Pendapatan dan Belanja

Todaro Michael. 2004. Pembangunan Ekonomi di Dunia Ketiga, edisi kedelapan, Yogyakarta: Penerbit Erlangga

Undang-Undang Nomor 17 Tahun 2003 Tentang Keuangan Negara (www.hukumonline.com)

Permendagri nomor 13 tahun 2006 Tentang Pedoman Pengelolaan Keuangan Pemerintah Daerah (http://hukum.unsrat.ac.id/men/permendagri_13_2006.)

Darise dan Nurlan, 2006. Pengelolaan Keuangan Daerah, Jakarta: PT Indeks Kelompok Gramedia

Sadono Sukirno, 2006. Makro ekonomi Teori Pengantar. Jakarta: PT.RajaGrafindo Persada.

Lincolin Arsyad, 2004, Ekonomi Pembangunan STIE Yogyakarta 